MINTAKAT: Jurnal Arsitektur

Volume 22, Issue 2, 2021, page 65-75

MINTAKAT: Jurnal Arsitektur

ISSN: 1411-7193 (Print), 2654-4059 (Online)

Universitas Merdeka Malang

\title{
RUMAH SAKIT DARURAT BENCANA DENGAN STRUKTUR PNEUMATIK TIUP
}

\author{
Muhammad Iqbal Nur Budiyantoputra ${ }^{1}$, Hery Budiyanto ${ }^{2 *}$, Nurhamdoko \\ Bonifacius $^{2}$ \\ ${ }^{1}$ Mahasiswa Magister Arsitektur, Pasca Sarjana, Universitas Merdeka Malang, \\ Jl. Terusan Raya Dieng Malang \\ 2Prodi Magister Arsitektur, Pasca Sarjana, Universitas Merdeka Malang, Jl. Terusan Raya Dieng Malang \\ *hery.budiyanto@unmer.ac.id
}

\begin{abstract}
ABSTRAK
Penelitian desain ini dimulai dari permasalahan penanganan penduduk yang sakit dan kebutuhan fasilitas medis darurat di daerah bencana. Kecepatan dan Efisiensi dalam penanganan bencana, tindakan pencegahan yang efektif, rehabilitasi dan pemulihan, penyampaian bantuan bencana yang tepat waktu akan meminimalkan hasil negatif setelah bencana terjadi. Penanggulangan bencana dimaksudkan untuk menampung banyak korban bencana dalam suatu bangunan yang layak huni dan nyaman, salah satu fasilitas penanggulangan bencana yang sangat dibutuhkan adalah Rumah Sakit Darurat Bencana, yang terdiri dari peralatan diagnostik dasar dan sarana yaitu: Triase, ICU, Ruang Operasi, Terapi / Perawatan, Ruang Konsultasi, Radiologi, Laboratorium / Diagnostik, Apotek. Sampai saat ini Fasilitas Rumah Sakit Darurat Bencana Terpadu belum tersedia di Indonesia, beberapa bencana yang terjadi di Indonesia hanya difasilitasi dengan posko kesehatan dengan tenda atau gedung gawat darurat yang dibangun dengan struktur dan teknologi konvensional yaitu tenda rangka baja dengan biaya yang tinggi dan waktu yang lama. untuk membangun. Oleh karena itu, RS Gawat Darurat Bencana membutuhkan suatu struktur yang dapat dibangun dalam waktu singkat dengan menggunakan struktur pneumatic air inflated. Konsep desain RS Emergency Disaster difokuskan pada kecepatan dan efisiensi penanganan pasien sehingga akan membantu proses penyembuhan. Metode penelitian untuk perancangan Rumah Sakit Darurat Bencana ini menggunakan desain berbasis bukti yaitu rancangan yang didasarkan pada bukti ilmiah berupa hasil penelitian sebelumnya dan penelitian sendiri. Terdapat 5 parameter dalam perancangan Rumah Sakit Darurat Bencana, yaitu: mobilitas, portable, modularitas, keamanan dan kenyamanan bagi pasien dan tenaga medis. Penataan massa bangunan rumah sakit darurat dirancang secara berjenjang, dimulai dari kebutuhan dasar pada awal bencana terjadi yaitu bangungan triase dan ruang operasi, selanjutnya berangsur-angsur dilengkapi dengan fasilitas kesehatan lain sehingga rumah sakit dapat berfungsi sebagaimana rumah sakit layaknya yang dapat menampung 150 pasien rawat inap.
\end{abstract}

Kata kunci : bencana, darurat, pneumatik, rumah sakit, tiup

\section{ABSTRACT}

This design research starts from the problem of handling the sick population and the need for emergency medical facilities in disaster areas. Speed and efficiency in disaster management, effective preventive measures, rehabilitation and recovery, timely delivery of disaster assistance will minimize negative outcomes after a disaster occurs. Disaster management is intended to accommodate many disaster 
victims in a habitable and comfortable building. One of the most needed disaster management facilities is a Disaster Emergency Hospital, which consists of basic diagnostic equipment and facilities, namely: Triage, ICU, Operation Room, Therapy / Nursing, Consultation Room, Radiology, Laboratory / Diagnostics, Pharmacy. Until now, Integrated Disaster Emergency Hospital Facilities are not yet available in Indonesia, some disasters that have occurred in Indonesia are only facilitated by health posts with tents or emergency buildings built with conventional structures and technology, namely steel frame tents with high costs and a long time to build. Therefore, the Disaster Emergency Hospital requires a structure that can be built in a short time using a pneumatic air inflated structure. The Emergency Disaster Hospital design concept is focused on the speed and efficiency of patient handling so that it will help the healing process. The research method for designing this Disaster Emergency Hospital uses an evidence-based design that is a design based on scientific evidence in the form of previous research and own research. There are 5 parameters in the design of a Disaster Emergency Hospital, namely: mobility, portable, modularity, safety and comfort for patients and medical personnel. The mass arrangement of the emergency hospital building is designed in stages, starting with the basic needs at the beginning of the disaster, namely the triage building and the operating room, then gradually being equipped with other health facilities so that the hospital can function as a proper hospital that can accommodate 150 inpatients

Keywords: air inflated, disaster, emergency, hospital, pneumatic.

\section{PENDAHULUAN}

Penelitian ini berangkat dari adanya masalah penanganan penduduk yang sedang sakit dan fasilitas darurat medis yang selalu muncul pada daerah bencana. Kejadian bencana yang sering terjadi di seluruh wilayah di Indonesia memerlukan kesiapan dan penanganan yang cepat dan efektif. Badan Nasional Penanggulangan Bencana menerbitkan "Pedoman Teknis Penanggulangan Krisis Kesehatan akibat Bencana" (Roswati et al., 2007) dan Peraturan Kepala Badan Nasional Penanggulangan Bencana Nomor 17 tahun 2009 tentang Pedoman Standarisasi Peralatan Penanggulangan Bencana, memberikan arahan bahwa kesiapan menghadapi bencana akan meminimalisir akibat-akibat yang merugikan melalui tindakan pencegahan yang efektif, rehabilitasi dan pemulihan serta pengiriman bantuan dan pertolongan secara tepat waktu. Bantuan dan pertolongan antara lain dimaksudkan agar korban bencana yang jumlahnya cukup banyak segera dapat ditampung dalam bangunan yang layak huni dan nyaman, salah satu fasilitas penggulangan bencana adalah Rumah Sakit Darurat Bencana .

Hingga saat ini belum terdapat fasilitas rumah sakit darurat bencana yang terpadu di Indonesia, beberapa kejadian bencana besar di Indonesia difasilitasi dengan posko kesehatan dengan menggunakan tenda atau bangunan darurat yang dibangun menggunakan struktur dan teknologi konvensional antara lain tenda dengan rangka terbuat dari baja yang memerlukan waktu lama serta biaya yang besar. Beberapa alternatif struktur bangunan rumah sakit darurat, antara lain disampaikan oleh Bakowski berupa „mobil hospital“ (Bakowski, 2016) yaitu rumah sakit darurat menggunakan truk kontainer yang diubah suai 
menjadi rumah sakit. Durumunda menyatakan bahwa rumah sakit lapangan paling tidak berupa tempat dan tenda yang dapat menampung minimal 10 bed pasien, satu ruang operasi dan satu laboratorium klinik (Durumunda et al., 2017). Rumah sakit darurat bencana memerlukan struktur yang cepat bangun, antara lain menggunakan struktur tiup yang rangkanya digelembungkan udara (air inflated structure). Struktur ini merupakan struktur bangunan yang menggunakan bahan berupa kain, karet, atau yang dibuat secara khusus untuk dapat penahan cuaca sehingga dapat tahan untuk digunakan dalam waktu lebih dari 10 tahun. Selain itu bahan Air Inflated Structure harus handal dan kuat terhadap gaya uji tarik hingga melebihi $200 \mathrm{~kg} / \mathrm{cm} 2$, daya tahan material terhadap suhu lebih dari 70 derajad selsius, pemasangan dan pembongkaran cepat. Struktur tiup dapat digunakan pada area terbatas, bahan struktur ringan, mudah dipindah, dilipat maupun diangkut ke lokasi lain (Budiyanto, Winansih, et al., 2018). Tulisan ini bermaksud menjelaskan bagaimana merancang rumah sakit darurat berdasarkan kebutuhan fasilitas kesehatan di kawasan bencana, dengan tujuan untuk membantu proses penanganan kesehatan bagi korban bencana. Sebuah rumah sakit darurat bencana untuk memenuhi kebutuhan fasilitas kesehatan di kawasan bencana yang cepat bangun, portable, modular, aman dan nyaman bagi pasien dan tenaga medis.

\section{TINJAUAN PUSTAKA}

Konsep perancangan rumah sakit darurat dirumuskan berdasarkan kebutuhan sarana kesehatan di kawasan bencana. Konsep tersebut kemudian diterjemahkan ke dalam gambar skematik perancangan berupa gambar arsitektur. Kebutuhan sarana sangat erat dengan solusi masalah kesehatan dalam kondisi bencana. Kebutuhan sarana harus menjamin terselenggaranya pelayanan kesehatan bagi korban akibat bencana dan pengungsi sesuai dengan standar minimal. Secara khusus, upaya ini ditujukan untuk memastikan: 1) Terpenuhinya pelayanan kesehatan bagi korban bencana dan pengungsi sesuai standar minimal; 2) Terpenuhinya pemberantasan dan pencegahan penyakit menular bagi korban bencana dan pengungsi sesuai standar minimal; 3) Terpenuhinya kebutuhan pangan dan gizi bagi korban bencana dan pengungsi sesuai standar minimal; 4) Terpenuhinya kesehatan lingkungan bagi korban bencana dan pengungsi sesuai standar minimal; serta 5) Terpenuhinya kebutuhan papan dan sandang bagi korban bencana dan pengungsi sesuai standar minimal (Widayatun \& Fatoni, 2013).

Dalam hal Rumah Sakit Darurat Bencana, Bakowski (Bakowski, 2016) menulis artikel tentang rumah sakit darurat tanggap bencana terdiri dari area gawat darurat yang dilengkapi bagian bedah dan diagnosis. Kriteria pendirian rumah sakit darurat terletak pada solusi pada aspek modularitas (kemampuan untuk mengemas fungsi ke dalam wadah kubik) dan mobilitas (kemudahan konstruksi untuk diangkut dari satu tempat ke tempat lain). Rumah sakit "darurat" terdiri dari peralatan diagnostik dasar dan ruang perawatan yang relatif 
sederhana, sesuai dengan ruang operasi atau resusitasi dengan mempertimbangkan organisasi ruang dan sirkulasi. Bagian gawat darurat terdiri dari: 1. daerah Triase, 2. trauma (resusitasi), 3. unit pengamatan, 4. terapi / perawatan, 5. Ruang tunggu, 6. konsultasi, 7. pendaftaran / penerimaan, 8. unit perawatan intensif, 9. laboratorium / diagnostik, 10. ruang operasi, 11. Koridor/selasar, 12. entri ambulans, 13. entri pejalan kaki.

Sementara Palupi (Roswati et al., 2007) menjelaskan bahwa Rumah Sakit Lapangan (RS Lapangan) merupakan unit pelayanan yang diciptakan untuk membantu fungsi pelayanan kesehatan rujukan (rawat jalan, rawat inap, emergency, kamar operasi, laboratorium, dll) yang dilaksanakan dalam kondisi darurat. Rumah sakit lapangan adalah rumah sakit yang didirikan karena adanya bencana dengan tujuan menyediakan perawatan kesehatan yang aman, menyediakan layanan untuk korban bencana serta pengobatan bagi pasien yang dirawat di rumah sakit sementara di lokasi yang aman. Menurut World Health Organisasi (WHO), rumah sakit lapangan adalah unit yang terdiri dari tempat, tenda, dan modul tiup yang memiliki setidaknya sepuluh tempat tidur, satu ruang operasi, satu laboratorium dasar serta peralatan rontgen portable (Durumunda et al., 2017). Terdapat dua katagori untuk fasilitas perawatan kesehatan yang berfungsi di zona bencana. rumah sakit lapangan yaitu bangunan permanen dan fasilitas yang dibangun sementara (Bitterman \& Zimmer, 2018). a) Rumah sakit permanen adalah unit medis yang berfungsi independen yang dipindahkan atau diangkut ke dan dari zona bencana sebagai unit lengkap, sesuai kebutuhan, rumah sakit ini memiliki tenaga sendiri dan alat bantu mobilitas yang terdapat di dalam strukturnya dengan menggunakan air, udara, atau tanah sebagai media transportasi. b) Fasilitas perawatan kesehatan sementara diangkut ke zona bencana sebagai elemen terpisah dan tidak berfungsi yang dibangun atau dipasang di lokasi dan kemudian dibongkar.

Struktur membran pneumatik merupakan salah satu sistem struktur soft shell, dimana struktur dapat berdiri akibat perbedaan tekanan udara di dalam struktur pneumatik dengan tekanan udara di luar struktur (Sukawi, 2011). Struktur pneumatik dibagi menjadi 2 kelompok besar yaitu air supported structure dan air inflated structure (Schodek, 2001). a) air supported structure yang disebut sebagai single membrane structure karena hanya membutuhkan satu lapis membran dan membutuhkan tekanan udara rendah (sekitar 1-2 psi). b) air inflated structure (struktur yang digelembungkan udara atau tiup) disebut juga double membrane structure. 

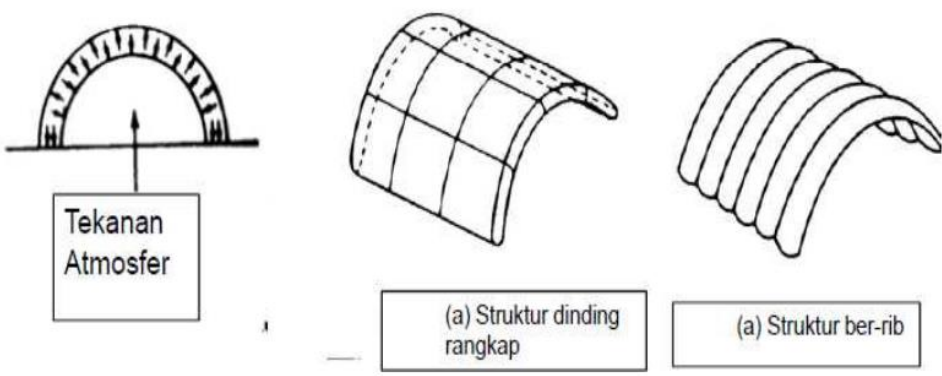

Gambar 1. Struktur yang Digelembungkan Udara

Sumber: Schodek, 2001

Struktur berbahan kain yang digelembungkan udara termasuk dalam kategori struktur yang ditegangkan dan mempunyai kelebihan yang unik dalam penggunaannya dibandingkan struktur tradisional. Keunggulan ini meliputi desain ringan, cepat dan mudah dipasang, cepat diangkut dan volume pengepakan kecil (Cavallaro \& Sadegh, 2006). Beberapa penelitian bangunan dengan struktur tiup antara lain: Tenda Tiup untuk Menampung Korban Bencana (Budiyanto, 2008; Setiawan \& Budiyanto, 2015) dan Atap Panggung Tiup (Budiyanto, Hery; Winansih, Erna; Setiawan, Aries Boedi; Iqbal, 2019; Budiyanto, Setiawan, et al., 2018) Keduanya menggunakan konsep struktur pneumatik tiup (air inflated) dengan bahan kain tarpaulin yang dilapisi bahan PVC. Struktur bangunan yang sesuai dengan fungsi rumah sakit darurat adalah struktur yang digelembungkan udara/tiup. Terdapat 5 (lima) parameter yang harus dimiliki oleh bangunan rumah sakit bencana dengan struktur tiup, (Iqbal et al., 2020) yaitu: mobilitas, modularitas, portable, keamanan, dan kenyamanan untuk pasien dan paramedis.

\section{METODE PENELITIAN}

Penelitian menggunakan pendekatan kualitatif dengan cara menyelidiki suatu fenomena yang ada sesuai dengan tujuan penelitian. Metode kualitatif dipilih karena permasalahan penelitian membutuhkan sejumlah data yang bersifat kontekstual dan mempunyai adaptabilitas tinggi selama proses penelitian, karena dalam proses penelitian ini sering menghadapi situasi yang berubah-ubah. Pendekatan penelitian termasuk pendekatan tanggap darurat bencana dan menggunakan evidence based design yaitu desain berdasarkan evidence scientific berupa hasil telaah data penelitian terdahulu dan penelitian sendiri untuk dijadikan sebagai dasar adanya masalah dan kebutuhan rumah sakit darurat. Metode perancangan dan penelitian secara skematik diuraikan pada Gambar 2, diawali dengan identifikasi permasalahan dan kebutuhan rumah sakit darurat, selanjutnya dilakukan analisis sehingga ditemukan masalahnya, berdasarkan permasalahan yang didapat maka dilanjutkan 
dengan penyusunan konsep rancangan yang mampu menjawab permasalahan perancangan sehingga produk akhirnya adalah skematik rancangan.

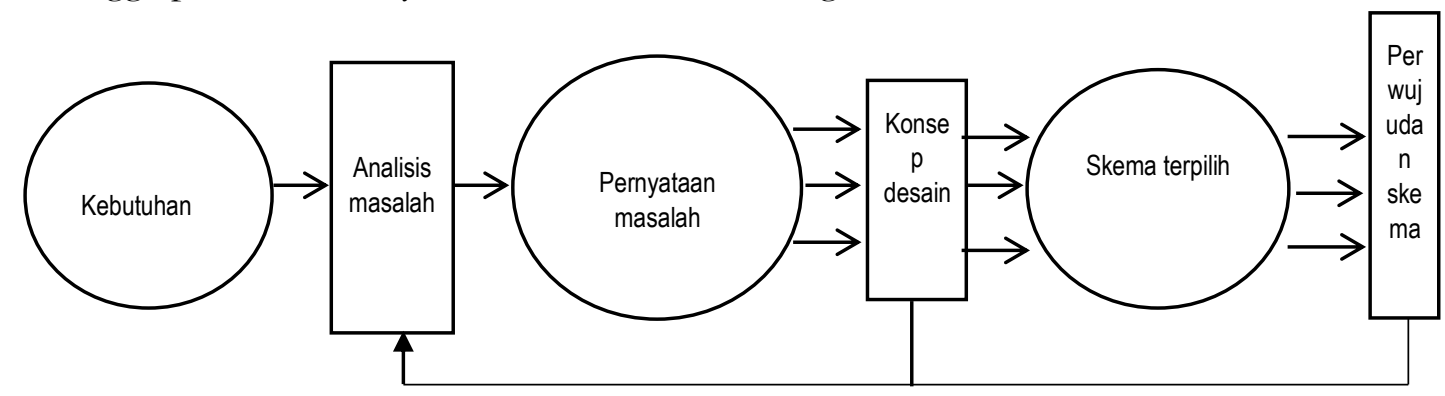

Umpan balik

Gambar 2. Alur Pemikiran Penelitian

\section{HASIL DAN PEMBAHASAN}

\section{Hasil Analisis Kebutuhan \& Persyaratan Ruang dalam Rumah Sakit Darurat Bencana}

Hasil penelitian terkait ruang rumah sakit bencana merupakan hasil kompilasi dari data teori dan observasi dengan disertai tinjauan terhadap Pedoman-Pedoman Teknis Dibidang Bangunan dan Sarana Rumah Sakit. Berdasarkan hasil penelitian jenis area pada rumah sakit bencana dapat dibagi menjadi 10 (sepuluh) area yang berdasarkan fungsi kegiatan pengguna bangunan (Iqbal et al., 2020; Roswati et al., 2007), yaitu: 1) Area unit gawat darurat \& triase, 2) Area bedah, 3) Area intensive care unit (ICU), 4) Area perawatan, 5) Area farmasi, 6) Area personel, 7) Area administrasi, 8) Area laundry dan sterilisasi, 9) Area x-ray dan Area processing film, 10) Area gudang.

\section{Konsep Utama Rumah Sakit Darurat Bencana dengan Struktur Tiup}

Konsep utama yang diterapkan pada Rumah Sakit Darurat dengan Struktur Tiup adalah :

1) Fast-Response, fasilitas rumah sakit yang cepat tanggap ketika terjadi bencana, cepat pendistribusian, proses pembangunan, dan penanganan pasien; 2) Healing, rumah sakit darurat yang dapat mempercepat proses penyembuhan dari bentuk, warna, serta sirkulasi udara, dan kebersihan, kenyamanan, kesterilan yang dapat mencegah masuknya bakteri, dan debu; 3) Bangunan Struktur Tiup, bangunan rumah sakit dengan struktur tiup yang cepat dalam pengangkutan, pemasangan, penggunaan dan pembongkaran.

\section{Konsep Koordinasi Modul}

Modul dasar yang merupakan suatu ukuran dasar dalam koordinasi modul dalam perencanaan ini dengan simbol M, maka $1 \mathrm{M}=30 \mathrm{~cm}=300 \mathrm{~mm}$. Sedangkan Multimodul yang merupakan kelipatan bilangan bulat dari modul dasar ditentukan dengan standar 3M 
yaitu $120 \mathrm{~cm}$ sebagai multimodul standar. Penerapan Koordinasi Modul Fungsional dalam perencanaan rumah sakit darurat ini dilakukan dengan membuat sistem acuan berupa sistem garis dan bidang yang dijadikan dasar pada tahap perencanaan teknis sebagai dasar ukuran dan perletakan komponen - komponen dan elemen - elemen bangunan.

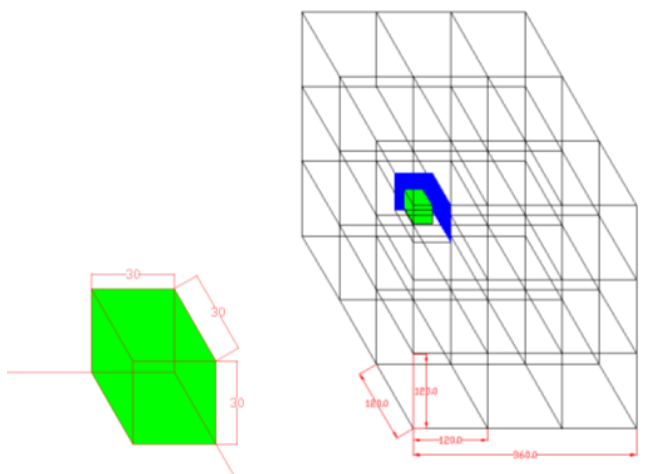

Modul dasar

Multi modul

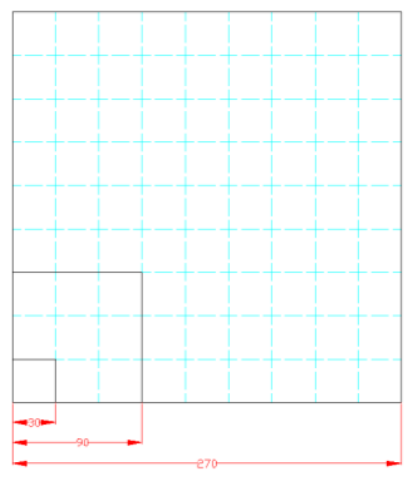

Koordinasi Modul

\section{Gambar 3. Koordinasi Modul Fungsional}

Modul struktur dirancang untuk menaungi fungsi-fungsi bangunan. Terdapat 2 (dua) system struktur, yaitu struktur tiup meliputi ruang-ruang utama menggunakan struktur tiup sedangkan fungsi penunjang yang karena aktivitasnya tidak dapat menggunakan struktur lunak maka digunakan kontainer yang sudah dimodifikasi sesuai fungsinya.

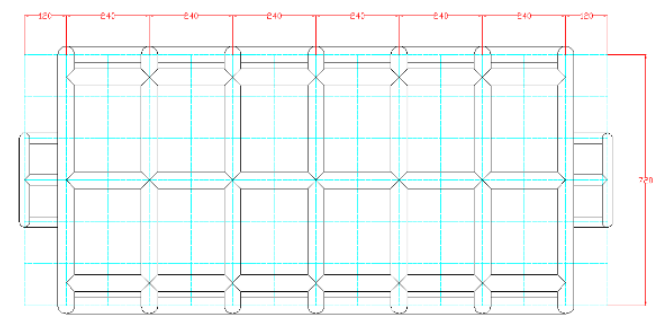

Rencana Atap

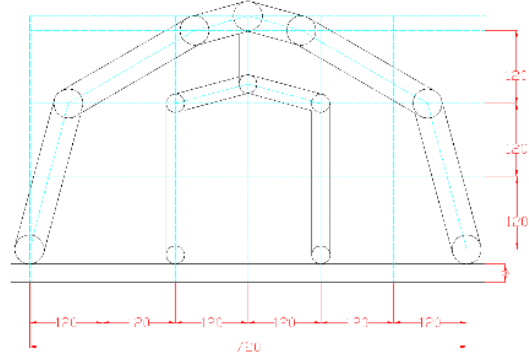

Potongan

Gambar 3. Modul Struktur Tenda Tiup

\section{Konsep Struktur Tiup untuk Rumah Sakit Bencana}

Struktur yang dipakai pada bangunan rumah sakit darurat bencana ini adalah struktur tiup (air inflated structure) disebut juga double membrane structure. Struktur membran pneumatik merupakan salah satu sistem struktur soft shell, dimana struktur dapat berdiri akibat perbedaan tekanan udara di dalam struktur pneumatik dengan tekanan udara di luar struktur. Prinsip struktur pneumatik terletak pada selaput/membran yang relatif tipis yang didukung oleh perbedaan tekanan. Dengan kata lain, tekanan dari ruang yang dilingkupi 
lebih tinggi daripada tekanan atmosfer. Perbedaan tekanan akan menyebabkan tarikan pada membran. Membran hanya bisa stabil apabila dalam keadaan tarik. Gaya tekan yang diinduksikan oleh gaya-gaya luar harus segera diatasi oleh peningkatan tekanan internal atau dengan menyesuaikan bentuk membran apabila membran tersebut cukup fleksibel. Tekanan udara yang diperlukan di dalam tabung kain struktur tiup minimal sebesar 2 Psi. Untuk mencapai hal tersebut maka pada setiap bangunan tiup dilengkapi dengan pompa udara yang otomatis akan bekerja apabila tekanan dalam tabung kerangka tiup kurang dari 2 Psi.

Sesuai dengan konsep modul struktur, maka lebar struktur bangunan tiup adalah $720 \mathrm{~cm}$, sedangkan panjang stuktur mengikuti fungsi bangunan dengan alternative sebagai berikut: 2 trave $(480 \mathrm{~cm}), 3$ trave $(720 \mathrm{~cm}), 4$ trave $(960 \mathrm{~cm}), 6$ trave $(1440 \mathrm{~cm})$.

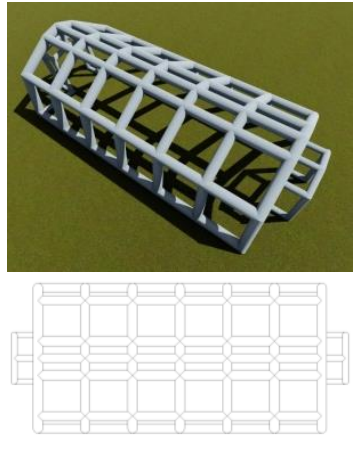

6 trave
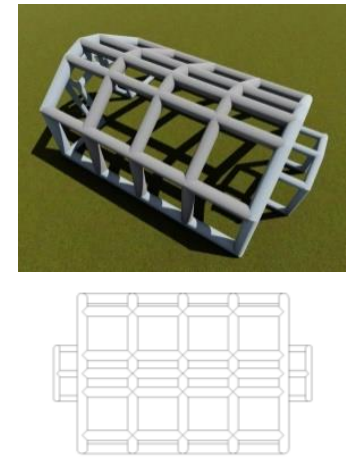

4 trave
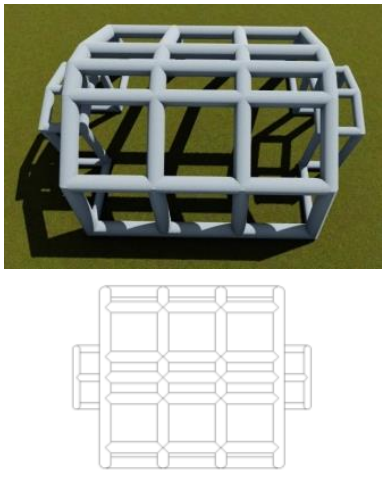

3 trave
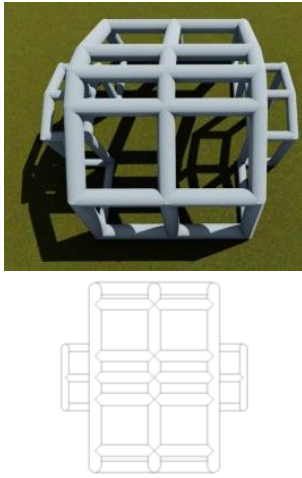

2 trave

\section{Gambar 4. Konsep Modul Struktur Tiup}

\section{Konsep Massa Bangunan Rumah Sakit Darurat Struktur Tiup}

Penataan massa bangunan rumah sakit darurat dirancang secara berjenjang, dimulai dari kebutuhan dasar pada awal bencana terjadi yaitu bangunan triase dan ruang operasi, selanjutnya berangsur-angsur dilengkapi dengan fasilitas kesehatan lain sehingga rumah sakit dapat berfungsi sebagaimana rumah sakit layaknya yang dapat menampung 150 pasien rawat inap.

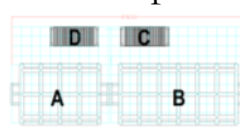

3 bed

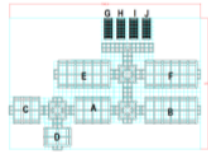

10 bed

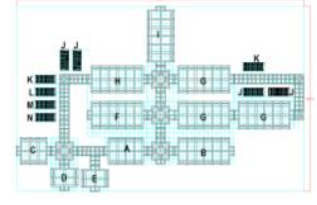

30 bed

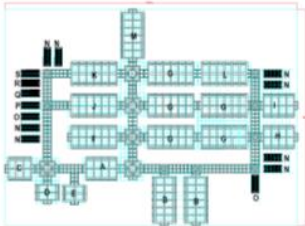

50 bed

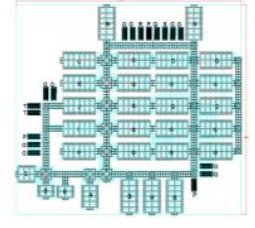

150 bed

Gambar 5. Konsep Massa Bangunan Rumah Sakit Darurat Struktur Tiup 


\section{Desain Rumah Sakit Darurat Bencana Struktur Tiup}
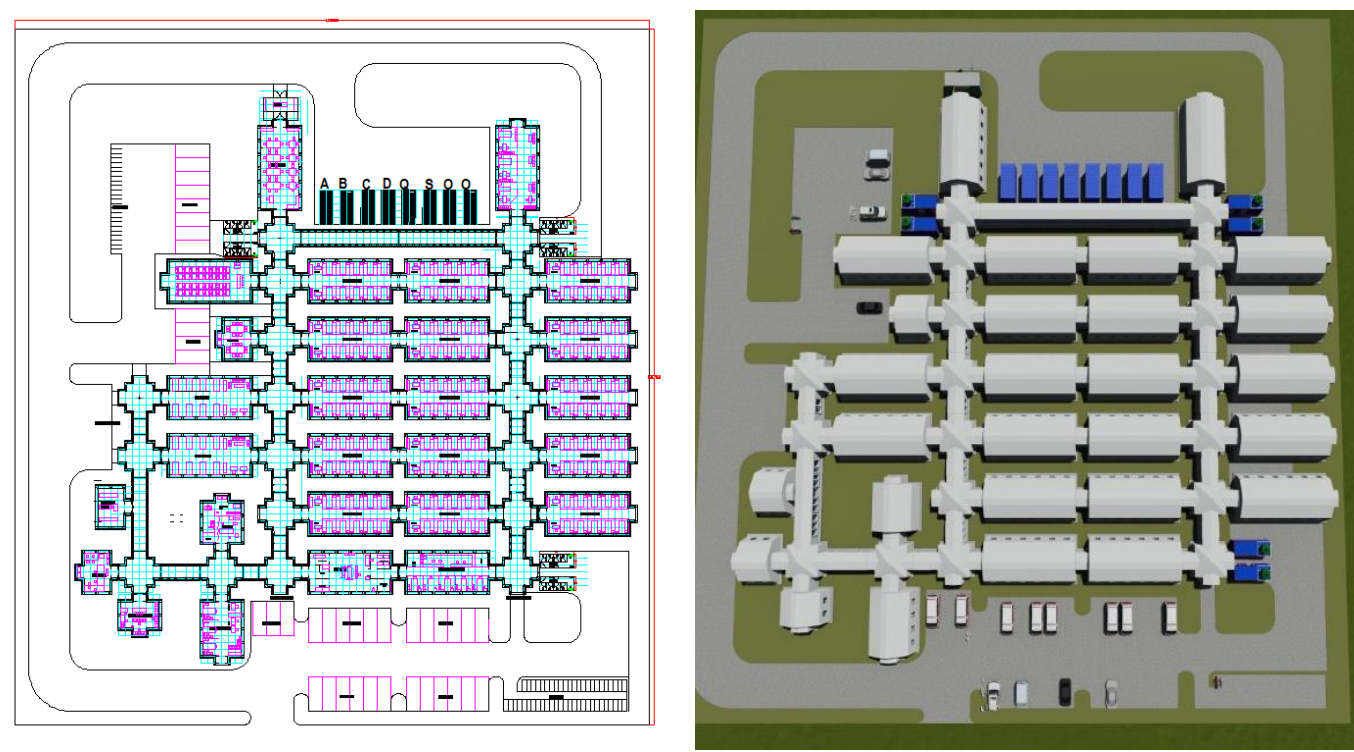

Gambar 6. Rencana Tapak Bangunan Rumah Sakit Darurat Struktur Tiup 150 bed
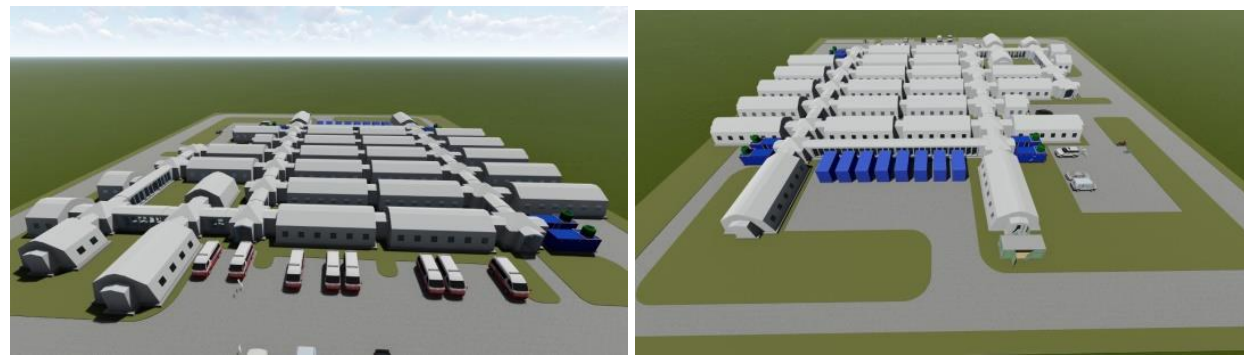

Gambar 7. Perspektif Eksterior Rumah Sakit Darurat Struktur Tiup 150 bed

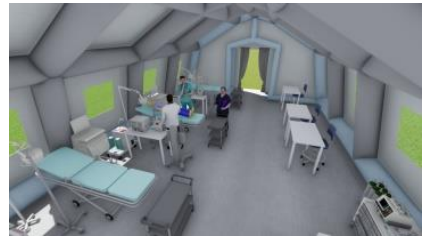

Triase

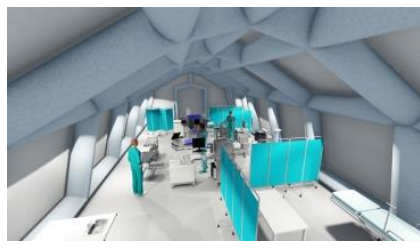

Operasi

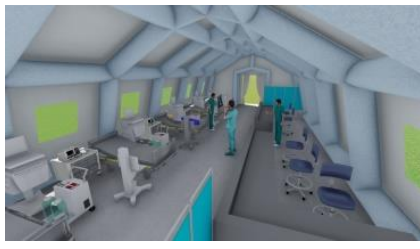

ICU

Gambar 8. Rencana Interior Bangunan Rumah Sakit Darurat Struktur Tiup

\section{Parameter Perancangan Rumah Sakit Darurat}

Dalam merancang rumah sakit darurat, maka terdapat 5 (lima) parameter yang harus dimiliki yaitu: mobilitas, modularitas, portable, keamanan, dan kenyamanan untuk pasien dan paramedis. Berdasarkan kelima parameter tersebut maka struktur bangunan yang paling sesuai adalah struktur bangunan pneumatik yang digelembungkan udara (tiup). 1) 
Parameter mobilitas dipenuhi antara lain ringan, cepat dan mudah dipasang, cepat diangkut dan volume pengepakan kecil. 2) Parameter modularitas dipenuhi dengan perencanaan fungsi dan struktur bangunan menggunakan koordinasi modular. 3) Parameter portable dipenuhi dengan system struktur yang mudah dipasang dan dibongkar dalam waktu tidak lebih dari 1 hari. 4) Parameter kemanan, dipenuhi dengan bahan struktur tiup menggunakan kain tarpaulin-PVC yang tahan dipakai selama 10 tahun. Parameter kenyamanan dicapai dengan stabilitas struktur dan fungsi bangunan, penggunaan warna yang soft, dan bahan kain yang lunak memberikan rasa nyaman bagi pasien dan paramedic.

Massa bangunan rumah sakit darurat bencana struktur tiup dibuat berjenjang, dimulai dari kebutuhan dasar pada awal bencana terjadi yaitu bangunan triase dan ruang operasi, selanjutnya berangsur-angsur dilengkapi dengan fasilitas kesehatan lain (laboratorium, farmasi, x-ray, ICU, rawat inap, kafetaria, gudang, dan lain-lain) sehingga rumah sakit dapat berfungsi sebagaimana rumah sakit layaknya yang dapat menampung 150 pasien rawat inap.

\section{SIMPULAN}

Untuk merencanakan dan membangun rumah sakit darurat, diperlukan 5 (lima) parameter yaitu: mobilitas, modularitas, portable, keamanan, dan kenyamanan untuk pasien dan paramedis. Rumah sakit darurat bencana memerlukan struktur yang cepat bangun, antara lain menggunakan struktur tiup yang rangkanya digelembungkan udara (air inflated structure). Struktur ini merupakan struktur bangunan yang menggunakan bahan berupa kain, karet, atau yang dibuat secara khusus untuk dapat penahan cuaca sehingga dapat tahan untuk digunakan dalam waktu lebih dari 10 tahun. Perancangan fungsi dan struktur bangunan tiup menggunakan koordinasi modular sehingga memudahkan dalam pemasangan, penggunaan dan pembongkaran serta mobilitas dari badanpenanggulangan bencana menuju lokasi bencana.

\section{REFERENSI}

Bakowski, J. (2016). A Mobile Hospital - Its Advantages and Functional Limitations. International Journal of Safety and Security Engineering, 6(4), 746-754. https://doi.org/10.2495/SAFE-V6-N4-746-754

Bitterman, N., \& Zimmer, Y. (2018). Portable Health Care Facilities in Disaster and Rescue Zones: Characteristics and Portable Health Care Facilities in Disaster and Rescue Zones: Characteristics and Future Suggestions. Journal of the National Association of EMS Physicians and the World Association for Emergency and Disaster Medicine, July. https://doi.org/10.1017/S1049023X18000560

Budiyanto, Hery; Winansih, Erna; Setiawan, Aries Boedi; Iqbal, M. (2019). Atap Panggung Struktur Tiup Energi Mandiri sebagai Sarana Usaha Kecil dan Menengah ( UKM ) memiliki peran sangat penting dalam pembangunan ekonomi nasional. Hal tersebut dikarenakan selain berperan terhadap pertumbuhan dan penyerapan tenaga kerja , 
juga. Seminar Nasional Sistem Informasi (Senasif) 2019, 1-8. https://seminar.unmer.ac.id/index.php/senasif/2019/paper/view/437

Budiyanto, H. (2008). Struktur Bangunan Tenda Pneumatik Sistem Knock Down Sebagai Tempat Penampungan Sementara Untuk Korban Bencana. In P. S. ITS (Ed.), Seminar Nasional Pascasarjana VIII - ITS (Issue 2008/08/13). Pasca Sarjana ITS.

Budiyanto, H., Setiawan, M. I., Winansih, E., Setiawan, A. B., \& Suntoro, H. (2018). Air Inflated Stage Roof Structure With Independent Energy For SMES Exhibition. Universitas Merdeka Malang (Ed.), 3rd International Conference of Graduate School on Sustainability (pp. 235-243). Graduate School of University of Merdeka Malang. https://seminar.unmer.ac.id/index.php/ICGSS/3ICGSS/paper/viewFile/326/217

Budiyanto, H., Winansih, E., Setiawan, A. B., \& Setiawan, M. I. (2018). Portable Stage and Pneumatic Air Inflated Roof Structure with Independent Energy as a Means of Exhibition of SME Products. International Journal of Scientific Engineering and Research (IJSER), 6(9), 48-51. http://www.ijser.in/archives/v6i9/IJSER18193.pdf

Cavallaro, P. V, \& Sadegh, A. M. (2006). Air-Inflated Fabric Structures. In P. V Cavallaro \& A. M. Sadegh (Eds.), Standard Handbook for Mechanical Engineers (11th ed., Issue November, $\quad$ pp. 1-27). McGraw-Hill. https://www.researchgate.net/publication/235213999_Air-

Inflated_Fabric_Structures

Durumunda, A., Tahliyesi, H., \& Hastanesinin, S. (2017). Evacuation of Hospitals during Disaster , Establishment of a Field Hospital , and Communication. Eurasian Journal of Medicine, 49(2), 137-141. https://doi.org/10.5152/eurasianjmed.2017.16102

Iqbal, M., Budiyanto, H., \& Bonifacius, N. (2020). The Parameters of Emergency Disaster Hospital with Inflatable Pneumatic Structure. In B. Ngarawula (Ed.), 5th International Conference of Graduate School on Sustainability (pp. 151-158).

Roswati, E., Khadijah, S., \& Widyastuti, P. (2007). Pedoman Teknis Penanggulangan Krisis Kesehatan akibat Bencana (E. Roswati, S. Khadijah, \& P. Widyastuti (eds.)). Departemen Kesehatan RI.

Schodek, D. (2001). Structures (4th ed.). Prantice Hall.

Setiawan, M. I., \& Budiyanto, H. (2015). Pengembangan Bangunan Air Inflated Structure sebagai fasilitas Tanggap Bencana. Seminar Nasional Teknologi (SENATEK), 873-880. https://doi.org/10.17605/OSF.IO/DKUHY

Sukawi. (2011). Struktur Membran dalam Bangunan Bentang Lebar. MODUL, 11(1), 2328. https://doi.org/10.14710/mdl.11.1.2011.\%p

Widayatun, \& Fatoni, Z. (2013). Permasalahan Kesehatan dalam Kondisi Bencana:Peran Petugas Kesehatan dan Partisipasi Masyarakat (Health Problems in a Disaster Situation: the Role of Health Personnels and Community Participation). Jurnal Kependudukan Indonesia, 8(1), 37-52. https://ejurnal.kependudukan.lipi.go.id/index.php/jki/article/view/21/15 